\title{
Fire-Climate Linkages in the Mid-Latitude Americas
}

Tucson, ARIzona, 23-28 March 2002

Climate, fire, and vegetation are interrelated elements of the earth system, and their variation and interaction through time have shaped the modern landscape. At annual and decadal scales and at the level of watersheds, climate/weather, vegetation composition, fuel buildup, and ignition frequency all determine the fire regime (i.e., the occurrence of fire, as well as its size and severity). On century and millennial temporal scales and landscape-to-regional spatial scales, however, climate determines both the fire regime and the potential vegetation composition. Consequently, the linkages between fire and vegetation are less clear on these long time scales.

Fire history and fire-climate linkages were discussed at this workshop attended by 70 scientists from Argentina, Australia, Canada, Chile, England, Mexico, Russia, Switzerland, and the United States. The purpose of the meeting was to bring together researchers who study past variations in fire activity as recorded by tree-ring and lake-sediment data and researchers who consider the climatic controls of fire. The similarities and differences between western North America and southern South America present an opportunity to study fire occurrence under an array of climate and vegetation conditions (Fig. 1).

Reconstructions of past fire occurrence during the last few centuries are based on tree-ring records and tree stand-age analysis, both of which offer high spatial and temporal resolution.

A second fire proxy, stratigraphic charcoal records from varved and non-varved lake and marine sediments, ice cores, peatlands, and soils have been used to reconstruct fire history across a range of latitudes. Because these records of fire activity span thousands of years, they provide information on the role of fire during periods of climate and vegetation change. Cathy Whitlock (United States) noted that highest fire activity in the Holo-

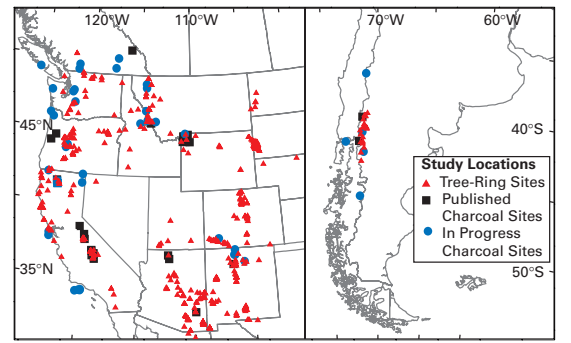

Fig. 1: Location of lake-sediment charcoal and tree-ring records from western North and South America.

cene was associated with centennial-to-millennial periods of drought, but the controls of fire on this time scale were sometimes overridden by shorter term variations. In northwestern North America, high fire frequency was associated with intensification of the subtropical high-pressure system, which occurred as a result of higher-thanpresent summer insolation in the early Holocene. In Patagonia, Maria Marta Bianchi (Argentina) and Patricio Moreno (Chile) showed highest fire activity (both frequency and magnitude) in the early Holocene and during the last few centuries.

The broad-scale climatic controls that give rise to conditions conducive to fires at the local scale were also described for North America and Patagonia by Patrick Bartlein (United States), Michael Flannigan (Canada), Tony Westerling (United States), Cary Mock (United States), Tim Brown (United States), and Henry Diaz (United States). The Iocation of mid tropospheric atmospheric pressure ridges, areas of rising air, and the seasonal variations in lightning occurrence are significant elements of western and northern North American fire climatology.

Fire and climate proxy records show a strong influence of annualto-decadal scale climate variability in fire occurrence. While the importance of El Nino-Southern Oscillation in the American Southwest and northern Patagonia was acknowledged, Ricardo Villalba (Argentina) emphasized that ENSO did not explain all fire variability on annual and decadal time scales.
The importance of retrospective fire-climate studies as a tool for fire management was also addressed. The legacy of past fires and periods of no fire also needs to be considered in strategies that attempt to restore forests to a prehistoric condition. While the effects of fire suppression policies are evident in low-elevation dry forests, fire history data suggests that fire suppression may have only limited impact in wet forests at higher elevation and along the coast, according to presentations by Carl Skinner, Alan Taylor, Peter Brown, and Fred Swanson (all from the United States). Moreover, projections of future climate changes indicate that fire activity in most regions will increase, suggesting the need for adaptive management in many regions.

Products of the workshop include the development of a firehistory database, a web page for further exchange of research ideas and public information, and a series of syntheses.

Sponsors of the workshop included the USDA Forest Service PNW Research Station, the IGBP Past Global Changes Program (PAGES), the U.S. Interagency Joint Fire Sciences Program, the NSF Earth Systems History Program (PEP-1 activity), the Inter-American Institute, and the University of Arizona.

\section{Cathy Whitlock \\ Patrick Bartlein \\ University of Oregon \\ Eugene, OR, USA \\ whitlock@oregon.uoregon.edu \\ bartlein@oregon.uoregon.edu}

\section{Thomas Swetnam}

University of Arizona

Tucson, AZ, USA

tswetnam@|trr.arizona.edu

This workshop report was edited substantially for brevity, a more comprehensive version is available on the PAGES website.

(http://www.pages.unibe.ch/ shighlight/shighlight.html) 